\title{
KEMUNGKINAN PENGGUNAAN TEKNOLOGI PELAPISAN PERMUKAAN DENGAN ULTRAVIOLET DAN BERKAS ELEKTRON DI INDONESIA
}

\author{
Oleh : Dwi Wahini Nurhajati
}

\begin{abstract}
Ultraviolet (UV) or electron beam (EB) curing coating technology is the crosslinking polymerization of a coating materials on a substrate (such as paper, metal, wood or plastic) via interaction with incident UV/EB irradiation, and this technology has been commercial used in a number of countries. The coating materials are monomer, oligomer or a mixture of monomer and oligomer. The crosslink polymer coated surface has been known to be resistant to water, organic solvent and heat. This paper gives an overview of the coating technology by ultraviolet or electron beam irradiation, and their applicability in Indonesia.
\end{abstract}

\section{INTISARI}

Teknologi pelapisan permukaan dengan ultraviolet (UV) atau berkas elektron (EB) merupakan proses polimerisasi ikat silang dari bahan pelapis secara langsung di atas substrat (misal kertas, kayu, logam maupun plastik) melalui insiden iradiasi sinar ultraviolet ataupun berkas elektron, dan teknologi ini sudah banyak digunakan secara komersial di berbagai negara. Bahan pelapis permukaan yang banyak digunakan adalah monomer, oligomer atau campuran keduanya. Permukaan yang telah dilapisi dengan polimer ikat silang dikenal tahan terhadap air, pelarut organik dan juga panas. Makalah ini akan memberi gambaran tentang kemungkinan penggunaan teknologi pelapisan permukaan dengan iradiasi ultraviolet ataupun elektron
di Indonesia. 


\section{ENDAHULUAN}

Penggunaan teknologi pelapisan dengan ultraviolet dan berkas elektron dalam ndustri telah dikenal sejak awal tahun 1970-an. Teknologi ini telah banyak nengganti teknologi pelapisan permukaan yang konvensional. Dibandingkan degan teknologi yang konvensional, teknologi pelapisan dengan ultraviolet dan erkas elektron mempunyai beberapa keunggulan antara lain :

. Kecepatan proses pelapisan sangat tinggi;

Tidak menimbulkan polusi udara karena tidak digunakan pelarut yang menguap;

. Permukaan substrat yang telah dilapisi bahan pelapis menjadi lebih tahan terhadap air, pelarut organik, panas dan goresan.

. Energi yang diperlukan menjadi lebih rendah dibandingkan dengan proses yang konvensional.

\section{PERBEDAAN ANTARA TEKNOLOGI PELAPISAN DENGAN UV DAN EB}

Teknologi pelapisan dengan UV biasanya digunakan untuk pelapisan yang serwarna terang, jemih atau hanya sedikit berisi pigmen. 'Curing' dengan UV untuk pelapis yang berwarna berat seperti hitam atau putih berjalan lambat. Warna nitam akan menyerap sinar UV, sedang warna putih yang mengandung titanium oksida memantulkan sinar UV. Sinar UV tidak dapat mencapai bahan pelapis yang dipenetrasi ke dalam substrat. Bahan pelapis yang tidak ter'curing' tetap tinggal sebagai cairan dan membahayakan kesehatan jika barang yang diproduksi itu dipasarkan dan sampai ke tangan konsumen.

Pelapisan dengan UV memerlukan photoinisiator yang menginisiasi proses polimerisasi, karena sinar UV sendiri tidak cukup 'energetic'. Photoinisiator harganya mahal dan juga menyebabkan bau yang kuat. Salah satu kelemahan teknologi pelapisan dengan UV yaitu bahan pelapis tidak dapat ter'curing' $100 \%$, sehingga penggunannya dalam industri bahan makanan (sebagai pembungkus dan produk-produk sejenisnya) sangat terbatas.

Elektron tenaganya lebih kuat, sehingga dapat mencapai permukaan bahan yang dilapisi pada kecepatan cahaya dan dengan energi sekitar $150 \mathrm{keV}$ sampai $300 \mathrm{keV}$ tergantung pada aplikasinya. Elektron-elektron tidak dipengaruhi oleh pigmen. Elektron juga dapat mengikat silang zat perekat yang terletak di antara 2 lapisan yang tidak jernih (misal aluminium foil) dan elektron mempunyai kemampuan untuk meng'curing' zat pelapis, tinta atau zat perekat, $100 \%$

Perbedaan-perbedaan lain antara teknologi pelapisan dengan UV dan EB ditinjau dari segi ekonomi, antara lain :

1. Kecepatan produksi menggunakan EB lebih tinggi
2. Semua proses yang menggunakan EB membutuhkan gas inert. Bahan yang dapat di'curing' dengan EB akan dihambat oleh oksigen jika di'curing' di udara, sehingga permukaan pelapisan menjadi lengket karena tidak ter'curing'. Sedangkan kebanyakan bahan pelapis untuk proses dengan UV dapat di'curing' di udara, kecuali 'UV silicon release coating' yang terbaru yang digunakan dalam pelapisan papan kayu.

3. Lampu UV sedikit lebih murah daripada sistem berkas elektron dapat $2-20 \mathrm{kali}$ lebih mahal daripada sistem UV pada lebar dan kapasitas yang sama.

Beberapa aspek perbedaan yang penting dari teknologi pelapisan dengan UV dan EB dapat diringkas sebagai berikut :

\begin{tabular}{|c|c|c|}
\hline & Ultraviolet & Berkas elektron \\
\hline Modal & rendah & tinggi \\
\hline Sumber energi & lampu merkuri & elektron percepatan \\
\hline Konsumsi energi & tinggi & rendah \\
\hline Aktivitas energi & rendah & rendah - tinggi \\
\hline Inisiasi & radikal bebas & elektron bebas \\
\hline Katalisator & photoinisiator & - \\
\hline Bahan pelapis & akrilat, dll & akrilat, dll \\
\hline Gas inert & - & memerlukan \\
\hline Kecepatan curing & detik & milidetik \\
\hline \multicolumn{3}{|l|}{ Penetrasi } \\
\hline - berwarna & 50 mikron & 400 mikson \\
\hline - jernih & 130 mikron & 500 mikron \\
\hline Konversi & $90 \%$ & $100 \%$ \\
\hline
\end{tabular}

\section{BAHAN PELAPIS}

Bahan pelapis dapat berupa monomer, oligomer atau campuran keduanya. Monomer yang banyak digunakan adalah akrilat karena cepat terpolimerisasi terutama jenis ester akrilat. Akrilat monofungsional akan memberikan polimer rantai lurus, tetapi dengan penambahan akrilat difungsional, trifungsional atau multifungsional, akan dihasilkan polimer rantai silang. Monomer akrilat yang banyak digunakan dalam industri pelapisan permukaan antara lain : heksana diol diakrilat (HDDA), dietilena glikol diakrilat (DEGDA), tripropilena glikol diakrilat (TPGDA), trimetilol propana triakrilat (TMPTA), gliseril propoksi triakrilat (GPTA), trimetilol propana etoksi triakrilat (TMPETA), dipenta eritritol heksaakrilat (DPHA), dll.

Penggunaan oligomer membantu mengurangi volatilitas, toksisitas, bau, penyusutan polimerisasi dan memperbaiki sifat-sifat bahan yang telah dilapis. Oligomer yang banyak digunakan dalam industri pelapisan antara lain : epoksi akrilat, poliester akrilat, oligoester akrilat, uretan akrilat, silikon akrilat, dll.

Vol. VII No. 12-13 1991/1992 


\section{HOTOINISIATOR}

Proses pelapisan dengan sinar ultraviolet sebagai sumber energi memerlukan hotoinisiator yang menginisiasi terjadinya proses polimerisasi karena sinar UV endiri tidak cukup "energetic" (tenaga penetrasinya rendah).

Photoinisiator adalah material yang setelah menyerap photon pada panjang elombang yang sesuai, akan terdisosiasi menjadi radikal dan menginisiasi proses limerisasi dengan adanya monomer/oligomer yang aktif. Beberapa jenis phooinisiator yang sering digunakan dalam industri pelapisan terdapat pada Tabel 1.

TABEL 1. PHOTOINISIATOR (2)

\begin{tabular}{|c|c|c|c|c|c|c|c|}
\hline \multirow{2}{*}{ hotoinisiator } & \multirow{2}{*}{$\begin{array}{l}\text { Berat } \\
\text { Molekul }\end{array}$} & \multirow{2}{*}{$\begin{array}{l}\text { Titik leleh } \\
{ }^{\circ} \mathrm{C}\end{array}$} & \multirow{2}{*}{$\begin{array}{l}\text { Titik didih } \\
{ }^{\circ} \mathrm{C}\end{array}$} & \multicolumn{3}{|c|}{ Kelarutan } & \multirow{2}{*}{$\begin{array}{c}\text { Panjang Gelombang } \\
\text { Efektif untuk } \\
\text { Eksitasi (nm) }\end{array}$} \\
\hline & & & & Air & etanol & eter & \\
\hline Biacetyl & 86,09 & $-2,4$ & $\begin{array}{l}86,4-87,5 \\
(750 \mathrm{~mm})\end{array}$ & 1 & $\sim$ & $\sim$ & $<450$ \\
\hline Acetophenone & 120,2 & 19,65 & 202 & sl & 1 & & \\
\hline Benzophenone & 182,2 & 48,1 & 305,9 & $\mathrm{tl}$ & 1 & 1 & $<400$ \\
\hline Michler's ketone & 268,4 & 179 & $\begin{array}{c}>360 \\
\text { (dekomposisi) }\end{array}$ & ssl & sl & sl & \\
\hline Benzil & 210,2 & $95-96$ & $346-348$ & ssl & 1 & 1 & $<450$ \\
\hline Benzoin & 212,2 & $137,6-138,6$ & $\begin{array}{r}343-344 \\
(750 \mathrm{~mm})\end{array}$ & tl & sl & 1 & $<400$ \\
\hline $\begin{array}{l}\text { Benzoin iso } \\
\text { butyl ether }\end{array}$ & 268 & $187-189$ & & u & 1 & 1 & \\
\hline $\begin{array}{l}\text { Benzil } \\
\text { dimethyl ketal }\end{array}$ & 256,3 & $63-66$ & & $\mathrm{tl}$ & 1 & & \\
\hline $\begin{array}{l}\text { Tetrame- } \\
\text { thylthiuran sulfide } \\
\text { Azobisiso- }\end{array}$ & 208 & 104 & & & 1 & ss1 & $<450$ \\
\hline $\begin{array}{l}\text { Azobisiso- } \\
\text { butyro nitrile }\end{array}$ & 164,2 & $\begin{array}{c}107 \\
\text { (dekomposisi) }\end{array}$ & & $\mathrm{t}]$ & 1 & 1 & $<400$ \\
\hline Benzoyl peroxide & 242,2 & 105 & & ᄂ & ssl & 1 & $<340$ \\
\hline
\end{tabular}

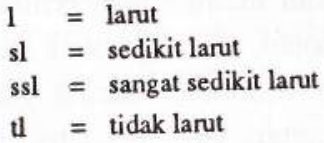

\section{KEMUNGKINAN APLIKASI PELAPISAN DENGAN UV/EB DI INDONESIA}

Pelapisan permukaan diperlukan untuk menjaga atau melindungi permukaan suatu benda yang penting seperti bahan bangunan, komponen kendaraan bermotor, alat-alat elektrik, dan lain sebagainya dari pengaruh cuaca, panas, pelarut ataupun goresan.
Di beberapa negara maju, teknologi pelapisan dengan ultraviolet banyak digunakan dalam industri : dekorasi logam, karpet vinil, pelapisan papan kayu, 'lithographic screen', photoresistor, 'integrated circuit (IC), printing plate, pelapisan optical fibre, pelapisan optical discs (laser vision video discs, compact disc audio discs), dan komponen elektrik lainnya, sedangkan pelapisan dengan proses iradiasi elektron dapat digunakan dalam industri seperti : pelapisan komponen plastik pada kendaraan bermotor, pelapisan mebel, pelapisan tangki bahan bakar pada sepeda motor, pelapisan permukaan genteng, pelapisan kertas dekorasi, pelapisan adesif, pelapisan roda baja, pelapisan permukaan pelat baja, pelapisan kertas yang dimetalisasi (yang digunakan untuk label, pembungkus sigaret, dll), pelapisan media magnetik pada film plastik tipis dan foil untuk pita video dan 'floppy disk', pelapisan kartu telepon, dsb.

Di Indonesia, perkembangan penggunaan barang hasil industri yang memerlukan proses pelapisan permukaan mulai dari barang kemasan, komponen barang elektronika, alat-alat rumah tangga, barang-barang keperluan dekorasi/interior, pelapisan papan kayu, printing, komponen kendaraan bermotor, barang-barang keperluan kantor sampai komponen alat audio-visual, akhir-akhir ini maju pesat. Mengingat keunggulan proses pelapisan menggunakan teknologi iradiasi sinar ultraviolet/berkas elektron, maka perlu dipertimbangkan pemakaiannya di Indonesia dalam berbagai produk industri yang memerlukan pelapisan permukaan. Bagi negara berkembang seperti Indonesia maka alih teknologi dapat dianggap sebagai salah satu jalan pintas untuk mengejar ketinggalan dalam teknologi dan industri terutama teknologi pelapisan permukaan dengan ultraviolet ataupun berkas elektron.

Salah satu hambatan aplikasi teknologi tersebut di Indonesia adalah penyediaan bahan pelapis yang berupa monomer maupun oligomer, karena bahan tersebut masih merupakan produk import, sehingga perlu dipikirkan kesinambungan penyediaan bahan tersebut.

\section{KESIMPULAN}

Dengan memperhatikan keunggulan teknologi pelapisan permukaan dengan proses iradiasi sinar ultraviolet ataupun berkas sinar elektron dibandingkan dengan teknologi yang konvensional maka sudah selayaknya perlu dipertimbangkan pemakaiannya di Indonesia karena mempunyai prospek yang cerah. 


\section{DAFTAR PUSTAKA}

1. Christmas,B., Kemmeren, R., Kosnik, F., dalam "High Performance Polymers: Their Origin and Development", Seymor, R.B., and Kushenbaur, ed., New York, hlm. 331-337, 1986.

2. Kato, S., Nakahara, S., Jpn. Paint Tech., 20, 145, 1981.

3. Lauppi. U.V., Radiat. Phys. Chem., 35, 30-35, 1990.

4. Papas, S.P., ed., 'UV Curing : Science and Technology', Technology Marketing Corp., Norwalk, Conn, 1978.

5. Randell, D.R., ed., Radiation Curing of Polymer, Special Publication No. 64, Royal Society of Chemistry, 1987. 